\title{
Spiritual Motherhood: Extraordinary Women in the Early Middle Ages
}

In late antiquity and the early Middle Ages, Christians added new shades of meaning to the notion of "mother" and to inherited ideas about motherhood. This does not imply that there were fundamental alterations in traditional medical definitions or physiological assumptions, which changed very little between the fourth and the tenth centuries. The legacy of Greek biological science was preserved in the learned tradition, although attenuated in the West by the general loss of educational and intellectual resources and confined increasingly to a narrowing group of literate people. By the sixth century, almost the only people in western Europe who could read were monks and nuns, so that monastic ideologies assumed an ever larger place in Christian consciousness. Within monastic institutions and through the writing and preaching of those associated with them, a new ideology of "spiritual" motherhood was constructed alongside ancient ideas about what mothers were. Crucial distinctions between physical and spiritual maternity were introduced, with far-reaching implications for women and children distant from centers of monastic learning and devotion.

By the end of the fourth century, Christianity was the established religion of the Roman world. No more Christian martyrs were persecuted in the western empire, and existing legal, administrative, and other institutions adapted gradually to the new faith 
and order. Christian emperors, challenged and advised by Christian bishops, ruled in Rome and Constantinople. The Church began to assume the majestic proportions that it would maintain for more than a millennium as the predominant institution of western Europe. As the higher clergy moved into positions of social, political, and educational as well as religious leadership, they acquired new duties and assumed roles much more extensive than those of the early shepherds of the flock. Later, with the decline of the empire and its institutions, the enormous prestige of Church and clergy compensated for severe practical limitations on ecclesiastical authority and effective means of control.

As a persecuted sect was transformed into a dominant and later an established church, conversion became a mass movement. Missionaries were free to make converts by teaching and preaching; Christian allegiance became helpful or even essential to success in many kinds of endeavor. Inevitably, some of the new Christians appeared shallow or lukewarm to their co-religionists. Membership in a state church bears little resemblance to identification with a persecuted minority, and significant losses accompanied the overall triumph of Christianity-chief among them a steady erosion of the intimacy and intensity of the earlier "family" of the beleaguered followers of Jesus. The rough equality of hard times, the comradeship across class and gender lines experienced by /for example) Perpetua and Felicitas, vanished along with persecution. Christians were quickly redivided into classes and degrees based on sex and status; the zeal once shared by all, with their willingness to die for the faith, became the property of a new elite. In the fourth and fifth centuries some heroic men and women continued to flee to the "desert" - now suggesting physical hardship and isolation rather than a specific place-while significant numbers entered monastic institutions, where they struggled to live perfect lives in community. Like their models and predecessors, the martyrs and the desert saints, these extraordinary Christians suffered for the faith and renounced "this world," including the comforts, obligations, and affections of traditional domesticity.

Monks and nuns built new families to replace the families left behind. They carried into the cloister images and meanings attached to such designations as "sister," "brother," "mother," 
and "father" and returned new definitions and relationships to the wider community. The language and imagery of an elite carry weight far beyond its numbers, particularly when it holds a nearmonopoly of the education and written records of a society. The renunciation of sexual activity and conventional family ties was essential to monastic ideology and practice, and the writers and thinkers and preachers who shaped Christian teaching in these centuries were, for the most part, monks. Their special perspectives played a critical part in forming Christian attitudes toward sexuality and domesticity, and because their words were written down, preserved, and taken seriously, they are critical still.

Many people, not only monks and nuns but those who supported them and depended on their prayers and services, believed that monasticism offered the "best" life for a Christian. It aimed at perfection, which was thought to be within the grasp of a celibate monk or nun but out of the reach of persons distracted from devotion to God by the things of this world, including families. St. Jerome, for one, believed that too much affection for one's children weakened one's love of God. ${ }^{1}$ In its everyday physical and social meanings, parenthood was excluded from the monastic world; candidates for the religious life were expected to eschew it if possible or, if they were already parents, to find a new focus for their interests, energies, resources, and affections. (This was true to an extent for both sexes but had different implications for men and women; I am concerned here with its significance for women and for motherhood.)

In the ancient world, maternity was women's sole or primary claim to status and significance. There were exceptional situations, but in general-and in societies as diverse as those of the Jews and the Romans-women without children were pitied, ignored, or despised. The earliest Christians upset these traditional values so that motherhood was neither an avenue nor an obstacle to honor and sanctity. In time, as Christian communities became increasingly hierarchical and their leadership exclusively male,

I. Jerome, letter 39 to Paula on the death of Blesilla, in Sancti Eusebii Hieronymi Epistulae, ed. Isidore Hilberg (Leipzig: G. Freytag, 1910), 1:293-308; CSEL, vol. 54 . 
women who aspired to holiness were restricted to forms of religious life in which physical motherhood was actually incompatible with devotion to God. Within the convents, however, and in influential circles outside, the world "mother" began to acquire new kinds of significance. If physical maternity was devalued, spiritual maternity soon took its place, so that "motherhood," transformed, retained a high status in medieval Christian ideology.

St. Jerome, writing near the turn of the fifth century, was an articulate and extreme representative of monastic views of family, sexuality, and the Christian life. He easily dismissed traditional filial piety when it got in the way of "higher" goals. His letters to friends and disciples are filled with concrete warnings about family burdens that interfere with the ascetic vocation. To a young man-not married but carrying heavy domestic responsibilitiesJerome wrote:

I know full well the fetters which you will say impede you. . . Your widowed sister clings to you to-day with loving arms. . . Y Your old nurse and her husband, who have the next claim to your affection after your own father, exclaim, "Wait for a few months till we die and then give us burial." ${ }^{2}$

The duty to bury one's parents properly was one of the most serious and sacred obligations of a Roman son, but Jesus called Christians to new responsibilities when he said, "Follow me, and leave the dead to bury their own dead" (Matt. 8:22). Like the martyr Perpetua, Jerome insisted on the superior claim of the new family:

But, you will say, the Scripture bids us to obey our parents. Nay, whosoever loves his parents more than Christ loses his own soul. The enemy takes up his sword to slay me: shall I think of my mother's tears? . . The battering-ram of affection which shakes faith

2. St. Jerome: Select Letters, trans. F. A. Wright /Cambridge, Mass.: Harvard University Press, I 980), letter I4, p. 33. Here Jerome takes for granted the quasiparental status of a nurse. 


\section{The Oldest Vocation}

must be beaten back by the wall of the Gospel: "My mother and my brethren are these, whosoever do the will of my father which is in heaven. ${ }^{\prime 3}$

Family affection is the devil's weapon, a battering-ram wielded by the powers of darkness; the mother's tears, summoning conventional sentiment, only weaken the resolve of a son of the true Father. Images of pathetic, clinging family members, which could be powerfully moving in another context, signify danger and treachery here; the passage from the Gospel is skillfully employed to shape the meaning of this collage of touching scenes.

The advice quoted above was written to a young man, but many of Jerome's fiercest admonitions were intended to persuade women of the advantages of virginity and celibacy over marriage and motherhood. He wanted young women to remain unmarried and widows to avoid remarriage, and he vehemently stated his indifference and contempt for the traditional duties and pleasures of a Roman matron-to carry forward her husband's "line" and gratify her father in his old age. He wrote to Furia, a widow: "Are you afraid that the line of Camillus will cease to exist and that your father will not have a brat of yours to crawl upon his breast and soil his neck with nastiness?" ${ }^{4}$ To Furia, Jerome trivialized the rewards of motherhood; this argument lacks the weight and force of the "battering-ram" that threatened the vocation of the young monk.

When Jerome wrote to Paula, his favorite Roman matron, however, he expressed the most profound admiration and respect for her choices. When she left Rome for Bethlehem, Paula chose a new life in Christ over "this world," including the children who remained in it. Jerome drew a poignant picture of Toxotius, the youngest, standing on the shore, hands outstretched toward his departing mother. ${ }^{5}$ Paula hardened her heart for Christ's sake, and Jerome responded with love and praise. He congratulated Paula and Melania (another widow who left her home and child in order to live in Jerusalem) for "scorning their wealth and deserting their

3. Ibid., pp. 33, 35 .

4. Ibid., letter 54, p. 233.

5. Jerome, Epistulae, letter I08.6, 2:3 I I CSEL, vol. 55. 
children [as they] lifted up the Lord's cross." ${ }^{\prime 6}$ To Jerome, wealth and children alike were "goods" to be left in the world unless they could be brought into religious life. Paula took some of her property to help establish her community in the Holy Land, and she took her daughter Eustochium, who was committed to virginity. She left behind her husband's property, her younger daughter, who was about to be married, and her son, who "belonged" to his father. ${ }^{7}$ (The attitudes toward children and property expressed in these letters were, of course, Jerome's. Evidence of Paula's feelings comes only from what he tells us and what we can infer from her behavior.)

A daughter offered a second chance to a mother who had missed her own opportunity: "Why, mother, grudge your daughter her virginity? She has been reared on your milk, she has come from your body, she has grown strong in your arms. Your watchful love has kept her safe. Are you vexed with her because she chooses to wed not a soldier but a King? She has rendered you a high service: from to-day you are the mother by marriage of God. ${ }^{\prime 8}$ The mother of that passage is nurturing, strengthening, protective, and loving, but those qualities are celebrated only in relation to the production and preservation of a virgin child. Jerome was sympathetic to mothers, but he found much of their work unappealing: "She carried you long, and she nursed you for many months; her gentle love bore with the peevish ways of your infancy. She washed your soiled napkins and often dirtied her hands with their nastiness. She sat by your bed when you were ill and was patient with your sickness, even as she had before endured the sickness of maternity which you caused. ${ }^{\prime \prime}$ Jerome wrote almost nothing about his own family; we do not know his mother's name. Physical maternity, for him, was difficult and heartbreaking, even disgusting, unless redeemed by a new relationship to virginity.

6. Jerome, Select Letters, 45, p. I 83.

7. Here I follow the analysis of Jo Ann McNamara in "Cornelia's Daughters: Paula and Eustochium," Women's Studies I I (1984), 9-27. See also Elizabeth A. Clark, "Friendship between the Sexes: Classical Theory and Christian Practice," in Jerome, Chrysostom, and Friends (New York: Edwin Mellen Press, 1979), pp. 35-108.

8. Jerome, Select Letters, 22, p. 95.

9. Jerome, Epistulae, letter I 1 7.4, 2:3 I 9. 
Such devaluation and disregard for conventional family ties did not express simply a desire to withdraw from the world the better to serve God. The attitudes of Christian intellectuals toward the human body and human relationships were strongly colored by the environment of late antiquity-a world in which many learned and serious people, Christian and pagan alike, tended to distrust the physical world and their own physical being. There are conflicting interpretations of the dualism and antimaterialism of the Mediterranean world in the second to fourth centuries of the Christian era, but all agree at least about the existence of a widespread detachment or distaste for human bodies and conventional human relationships. ${ }^{10}$ In the Neoplatonic tradition of patristic Christianity, body and soul were distinct and separate, and spiritual reality was valued far above the material. Indeed, in significant respects the spiritual world was the real world: St. Augustine remembered that "by reading these books of the Platonists I had been prompted to look for truth as something incorporeal."11

Dualism could go far beyond orthodoxy, as Augustine knew very well. Christians were bound to a God who not only created the material universe but entered it: their God was born, suffered, and died a human being. Nonetheless, the holiest men and women in the ancient world seemed to act out in their bodies and lives the intellectual dualism of the elite. One of the Desert Fathers accounted for his abuse of his body by saying: "I am killing it because it is killing me." ${ }^{12}$ The "it," the body, was separate from

Io. See esp. E. R. Dodds, Pagan and Christian in an Age of Anxiety (Cambridge: Cambridge University Press, I 985), chap. I. For a different interpretation, see Peter Brown, The Body and Society: Men, Woman and Sexual Renunciation in Early Christianity (New York: Columbia University Press, 1988). Brown argues that the emphasis on virginity and celibacy should be understood in part as a social phenomenon-that ascetics, by "dying" to the family and the state, disqualified themselves for childbirth and for military service and thus escaped society and its demands.

I I. Augustine, Confessions VII.20, trans. R. S. Pine-Coffin (London: Penguin Books, I 96 I), p. I 54.

I 2. Heraclidis Paradeisos I, cited in Dodds, Pagan and Christian, p. 30. Harry Stack Sullivan's notion of the "not-me," constructed out of unbearable anxiety, helps to describe, if not to explain, the "awe, dread, loathing, and horror" expressed toward the body, sexuality, and women in some of these writings; see The Interper- 
the "me," the soul. The body detracted from goodness and wisdom and closeness to God and endangered the soul; " $\mathrm{it}$ " required discipline. Men like Jerome, who feared the power of their bodies and especially of their sexuality, easily transferred their fear and disgust to the women who were objects of longing and occasions of conflict. Their interpretations of the Fall captured a psychological truth, for they distinguished the "self"-Man, or soul, or the rational aspect of human nature-from the Other: Woman, or body, or the carnal aspect. The rejected aspect of human nature was assigned to Eve, a creature like and unlike her "mother," Adam.

The desert saints did not privilege motherhood; female parents did not escape the fear and disgust attached to women's bodies. Among their tales is the following:

A certain brother was going on a journey, and he had his mother with him, and she was old. They came to a certain river, and the old woman could not cross it. And her son took off his cloak and wrapped it about his hands, lest he should in any wise touch the body of his mother, and so carrying her, he set her on the other side of the stream. Then said his mother to him, "Why didst thou so cover thy hands, my son?" He answered, "Because the body of a woman is fire. And even from my touching thee, came the memory of other women into my soul." ${ }^{13}$

Only women who remained entirely apart from sex and physical maternity avoided the identification of the female with flesh and sin and death. The descendants of Eve were punished by subjection to men and by suffering in childbirth, but because virginity was the state of our original creation, a virgin could escape the double curse. Jerome told Paula's daughter Eustochium:

sonal Theory of Psychiatry, ed. Helen Swick Perry, Mary Ladd Gawel, and Martha Gibbon (New York: Norton, I 953), p. 3 I 5 . Margaret Miles believes that beginners in the ascetic life were especially likely to feel the need to "discipline" their bodies; see Fullness of Life: Historical Foundations for a New Asceticism (Philadelphia: Westminster Press, I 98 I), p. 60.

I 3. The Desert Fathers, Helen Waddell, ed. (Ann Arbor: University of Michigan Press, I 981 ), p. 7. 


\section{The Oldest Vocation}

You must not be subject to the sentence whereby condemnation was passed upon mankind: 'In pain and in sorrow shalt thou bring forth children.' Say to yourself: "That is a Law for a married woman, but not for me." ...

Eve in Paradise was a virgin: it was only after she put on a garment of skins that her married life began. . .

That you may understand that virginity is natural and that marriage came after the Fall, remember that what is born of wedlock is virgin flesh and that by its fruit it renders what in its parent root it had lost. ${ }^{14}$

Death came into the world with the Fall, making sexual reproduction necessary to replenish the human race, but only until the birth of Christ. For the patriarchs and their wives, fruitfulness was a blessing and barrenness a curse. Before Christ, "the world was empty of people, and ... the only benediction possible was the gift of children." All that changed with the second Adam, born of the second Eve-another virgin, like Eve before the Fall: "Death came through Eve: life has come through Mary. For this reason the gift of virginity has been poured most abundantly upon women, seeing that it was from a woman it began."15

The Church Fathers, as a group and as individuals, were as inconsistent as other human beings, and the work of each was shaped by his unique experience-social, intrapsychic, and material as well as religious. Unlike Jerome, St. Gregory of Nyssa came from a prominent family of bishops and saints. (One of his brothers was Basil the Great, the most important of the eastern monastic founders and the author of an influential monastic rule.) Among Gregory's writings are a treatise on virginity and a life of his sister Macrina, who founded a community of ascetic women. The treatise catalogues the horrors of marriage and parenthood, including widowhood and parental bereavement. Mortal children, according to Gregory, were born to die:

For the bodily procreation of children . . . is more an embarking upon death than upon life for man. Corruption has its beginning in birth

I 4. Jerome, Select Letters, 22, pp. 91, 93.

I 5. Ibid., pp. 97, 99 . 


\section{SPIRITUAL MOTherhood}

and those who refrain from procreation through virginity themselves bring about a cancellation of death by preventing it from advancing further because of them, and, by setting themselves up as a kind of boundary stone between life and death, they keep death from going forward. ${ }^{16}$

The common identification of sexuality and reproduction with death is particularly striking here. Special horrors awaited mothers, and Gregory noted their terrible fear and suffering: "Children born and not born, living and dying, are alike the source of pain. ${ }^{\prime 17}$

The argument of "On Virginity" is extreme, and extremely dualistic, but internally logical and consistent if its premises are accepted. When it is placed beside Gregory's "Life of St. Macrina," however, major inconsistencies are revealed. Macrina was a virgin saint of incomparable wisdom and virtue, a woman so holy that Gregory was not sure it was "right to use that natural designation for one who went beyond the nature of a woman." As "the earliest flowering of our mother's womb," Macrina was the oldest of nine siblings in this remarkable family. ${ }^{18}$ The mother herself was a pure and holy woman. Although she would have preferred to remain unmarried, as a beautiful orphan she was in danger of abduction and rape, so she selected a husband as a kind of "guardian for her own life. ${ }^{\prime 19}$ When Macrina was about to be born, her mother fell asleep and: "seemed to be holding in her hands the child still in her womb, and a person of greater than human shape and form appeared to be addressing the infant by the name of

16. Gregory of Nyssa, "On Virginity," I 4, in Saint Gregory of Nyssa: Ascetical Works, trans. Virginia Woods Callahan (Washington, D.C.: Catholic University of America Press, I 966), p. 48.

17. Ibid., 3, p. I 9.

18. Gregory of Nyssa, "The Life of St. Macrina," in Ascetical Works, p. I 63.

19. Ibid., p. I 64. The assumption that women without fathers or husbands were vulnerable to rape and abduction lives in the background of ascetical writings; women based their choices on harsh realities. In the very different (perhaps harsher) world of the seventh-century Franks, a royal widow-convinced that her daughter would be raped or seduced after the king's death-had the girl tonsured and built a convent to which they both retired; see "Vita Sanctae Geretrudis," in SRM, Vol. 2, ed. Bruno Krusch (Hanover: Hahn, I 888), pp. 455-456. 
Thecla ... as she awoke from her sleep she saw the dream realized. ${ }^{20}$

The mother's dream foretold the daughter's greatness, and the name "Thecla" identified her sanctity with virginity through association with the heroic Thecla of the Apocryphal Acts. Macrina was betrothed at an early age, but when her young fiancé died, she refused to marry anyone else, claiming a widow's status. She protected herself from suitors by "a resolve never to be separated for a moment from her mother, so that her mother often used to say to her that the rest of her children she had carried in her womb for a fixed time, but this daughter she always bore, encompassing her in her womb at all times and under all circumstances." 21

The relationship of mother and daughter came to resemble that of an abbess and a nun, although their roles kept shifting throughout their lives together: "Certainly, the companionship of her daughter was not burdensome or disadvantageous for the mother, because the care she received from her daughter surpassed that of many of her maidservants and there was an exchange of kindly offices between them. The older woman cared for the younger woman's soul and the daughter for her mother's body, fulfilling in all things every desirable service." Macrina baked her mother's bread, shared her worries, and ultimately involved her in the life of "philosophy, drawing her on little by little to the immaterial and simpler life. ${ }^{\prime 22}$ In the new family of religion, Macrina became the spiritual mother of her own mother as well as her physical caretaker; the humbler chores were elevated by humility and love.

Gregory greatly admired the woman who had raised her children to be saints and whose life ended so beautifully: "Having come to a rich old age, [she] went to God, taking her departure from life in the arms of ... her children." ${ }^{23}$ Macrina is the protagonist of the "Life," but the mother is central too-blessed in her motherhood and in her children, whose sanctity made her a benefactor to the world. Sorrow and trouble could not prevail over such gifts; the

20. Gregory, "Life of Macrina," p. I64. For the uses of stories about Thecla, virgin and teacher, see MacDonald, The Legend and the Apostle.

2 I. Gregory, "Life of Macrina," p. I 66.

22. Ibid., pp. I 66-167.

23. Ibid., p. 172 . 
sons and daughters whom she bore and educated became in turn her parents. The message of the "Life," which deals with Gregory's own family and was shaped by his experience and deep emotion, runs almost directly counter to the message of "On Virginity." Two kinds of motherhood are represented, and Gregory's distaste for physical maternity, expressed so strongly in the treatise, is overpowered by experience in the family memoir. There, the physical motherhood of one woman is transformed into the spiritual motherhood of the other; physicality is redeemed by association with holiness. Because the two works belong to different genres with different conventions, Gregory never had to address the inconsistency, but it is apparent that he perceived his mother, as well as his sister, as wholly exceptional and her motherhood therefore inapplicable to the experience of other women.

Inconsistency and ambivalence notwithstanding, in their theoretical writings and explicit valuations the Church Fathers prized virginity as the best way of life for any Christian. They frequently cited the parable of the sower and the seed to measure the relative status of marriage, widowhood, and virginity: the goodness of marriage was thirtyfold; of widowhood, sixtyfold; of virginity, a hundredfold. For Augustine of Hippo, the three fruits of marriage were the mutual fidelity of the partners, the procreation and Christian upbringing of children, and the representation in the marital bond of the indissoluble relationship of Christ and the Church. Augustine held a higher view of marriage than either Jerome or Gregory, but not a higher view of procreation. Offspring were not essential to the goodness of marriage; indeed, its highest form might be based on a mutual vow of continence. He knew from experience that children were not born Christian; they had to undergo a second birth through their true mother, the Church. ${ }^{24}$

Augustine's thoughts and feelings about motherhood are not fully revealed in his theoretical statements about the value of procreation or the status of virgins. Like Gregory, he was the son of a remarkable woman, and he wrote at length about his mother, their relationship, and her role in his life. He saw Monica as the

24. Augustine (Confessions I.7, p. 28) said of babies that if they "are innocent, it is not for lack of will to do harm, but for lack of strength." 
agent of his conversion and perhaps of his salvation: "In the flesh she brought me to birth in this world: in her heart she brought me to birth in your eternal light. ${ }^{\prime 25}$ Like the mother of Gregory of Nyssa, Monica was entirely exceptional, achieving spiritual as well as physical maternity. The power and grace of her maternal passion were recognized by the Church in the person of the bishop who said "It cannot be that the son of these tears should be lost." For such a woman, evangelism begins when her child is born and becomes more intense as he grows: "Words cannot describe how dearly she loved me or how much greater was the anxiety she suffered for my spiritual birth than the physical pain she had endured in bringing me into the world." Augustine shared the contemporary belief that moral and spiritual qualities were ingested with the milk of mother or nurse. Monica's milk, and her tears, kept him afloat in the "hissing cauldron of lust" ${ }^{26}$ in which he spent his recalcitrant adolescence.

Augustine's Confessions offer an intimate, extended account of his childhood, his early relationships and their significance to him, and his experience of Monica from the close and passionate perspective of a favorite child. As a historical document his autobiography is unique: there was nothing like it in its own time, or for hundreds of years thereafter. It would be wrong to attach too much significance to the experience of such an unusual mother and son; we cannot assume that the Confessions is descriptive of motherhood in general. Nonetheless, its portrait of two extraordinary individuals helps to balance the other surviving sources from their era and environment-treatises, arguments, and polemics about the status of marriage and the hierarchy of souls.

By the fifth century, Christian thinkers and writers had transformed values and attitudes derived from their Jewish roots, the Roman environment, and the late classical thought-world into complex but identifiable Christian ideologies of family and sexual-

25. Ibid., 9.8, p. I 92 . See Clarissa W. Atkinson, "'Your Servant, My Mother': The Figure of St. Monica in the Ideology of Christian Motherhood, "in Immaculate and Powerful: The Female in Sacred Image and Social Reality, ed. Clarissa W. Atkinson, Constance H. Buchanan, and Margaret R. Miles (Boston: Beacon Press, I985), pp. I39-172.

26. Augustine, Confessions 3.1 2, p. 70; 5.9, p. I02; 3.I, p. 55. 
ity. It is much more difficult to establish a corresponding transformation in people's experience, although we may surmise that to bear and raise a child where motherhood was always considered a lesser good was to assume a special psychological burden, and perhaps a social and economic burden, even for women who did not receive letters from Jerome. Little of our information comes from mothers; most of it reflects the views and experience of the celibate, learned men who shaped Christian faith and morals in the first centuries. For these men, procreation-and therefore motherhood-was an aspect of Creation and Fall. Human sexuality, deeply flawed by sin, was redeemed to a degree by parenthood. Eve, and through her all women, might be saved "through bearing children" (I Tim. 2:15). Children were among the "goods" of marriage, and maternity a necessary contribution to the economy of salvation. And yet by the fifth century virginity was much more holy than motherhood. An individual mother-Monica, or the mother of Gregory and Macrina-might be a paragon or even a saint, but only in the context of her relationship with extraordinary children and only when that relationship shifted from the ordinary into the spiritual realm. Early medieval Christians received from their Fathers a profound ambivalence about sex, family, and motherhood, a legacy they carried into the extensive missionary enterprises that occupied the western Church in the early Middle Ages.

In the fourth, fifth, and sixth centuries of the Christian era, the churches and their bishops moved into the power vacuum created by the deterioration and collapse of imperial institutions in the West. Shifting principalities ruled by petty kings could not establish a stable political system, and the failure of Justinian's attempt to reunite the empire only confirmed the split between Rome and Byzantium. Western Catholics were left on their own to confront heresy, disorder, famine, and plague. At the end of the sixth century, the bishop of Rome responded to the crisis by turning the face of his church toward the West, where he hoped to find new resources and new allies. The gradual conversion to Christianity and cultural assimilation of the Germanic peoples of northern and western Europe had begun long before, but under Gregory the 
Great, mission became ecclesiastical policy. Bede, the eighth-century Anglo-Saxon historian, identified Gregory as the apostle who "transformed our still idolatrous nation into a church of Christ." Bede's careful, detailed account of the conversion of the AngloSaxons and the establishment of Roman Christianity in England supplies much of what is known about the encounter of cultures that created medieval Christianity. His Historica Ecclesiastica lays bare the complex processes of mission, conversion, and acculturation.

Among the valuable documents incorporated in Bede's history are letters exchanged by Gregory the Great and the missionary bishop Augustine of Canterbury-correspondence that illuminates the establishment of a foreign institution and ideologies within a host culture and society. Among the questions that worried the bishop were those relating to rules and customs governing marriage, family, and sexual behavior. "To what degree may the faithful marry with their kindred?" he asked. "And is it lawful for a man to marry his step-mother or sister-in-law? ${ }^{\prime 28} \mathrm{With}$ respect to family and motherhood, Augustine's eighth question is especially relevant:

May an expectant mother be baptized? How soon after childbirth may she enter church? And how soon after childbirth may a child be baptized if in danger of death? How soon after child-birth may a husband have relations with his wife? And may a woman properly enter church at the time of menstruation? And may she receive Communion at these times? And may a man enter church after relations with his wife before he has washed? Or receive the sacred mystery of Communion? These uncouth English people require guidance on all these matters. ${ }^{29}$

The questions and answers provide some information about the new "people of God" but much more about the missionaries. They set out to carry the Gospel to the pagans, but their Gospel was

27. Bede, History 2.I, p. 94.

28. Ibid., I.27, p. 74 .

29. Ibid., pp. $76-77$. The last comment reveals a sense of superiority that was harmful to Augustine's relations with his see, although Gregory warned him particularly to beware of pride (I.3I, p. 88). 
embedded in six hundred years of history and supported by a framework of cultural norms and assumptions that included a specific set of distinctions between sacred and profane. The Romans' notions of pollution and taboo were not like those of their hosts. Their sexual and marital arrangements were different, and interactions between the two groups were affected by the missionaries' commitment to celibacy. ${ }^{30}$ Augustine described the AngloSaxons as "uncouth" in sexual matters; unfortunately, we have no record of Anglo-Saxon opinion of the habits and behavior of the Romans. As always, the first opportunities for historical interpretation belonged to the conquerors and their successors. In this instance they belonged to Bede, an Anglo-Saxon Christian monk who traced his significant ancestry, his true lineage, to the Roman pope rather than the English converts.

The correspondence of pope and bishop is one-sided in relation to the Anglo-Saxons but still revealing. Gregory's answers show him to be a moderate in matters of sex and marriage. Reminding Augustine that "the fruitfulness of the flesh is no offence," he asserted that expectant mothers could be baptized. God's "gift of grace," by which he meant a pregnancy, was not "contrary to the sacred mystery by which all guilt is washed away." Making use of an allegorical interpretation of Scripture, the pope tempered the Law. The Hebrew rule of thirty-three days of "pollution" following the birth of a male child, sixty-six for a female, "is to be understood as an allegory, for were a woman to enter a church and return thanks in the very hour of her delivery, she would do nothing wrong." Neither pregnancy nor childbirth was to be treated as pollution; even a menstruating woman was allowed in church, "for the workings of nature cannot be considered culpable, and it is not just that she should be refused admittance, since her condition is beyond her control." The favor shown by Jesus toward the bleeding woman was extended to others of her sex. Nature was fallen, and its "workings" were understood to be especially difficult and painful for women. Their pains were acceptable; their

30. For a discussion of some of the differences between Germanic-pagan and Roman-Christian ideas about marriage, see Raoul Manselli, "Vie familiale et éthique sexuelle dans les pénitentiels," in Famille et parenté dans l'Occident 


\section{The Oldest Vocation}

suffering entitled them to compassion and consideration from church and clergy. ${ }^{31}$

Yet there was a darker side to Gregory's message concerning women and sex. "The fault," he wrote, "lies in the bodily pleasure, not in the pain; the pleasure is in the bodily union, the pain is in the birth, so that Eve, the mother of us all, was told: 'In sorrow thou shalt bring forth children.' "32 Pleasure was the enemy, and the special enemy of married people; the pope spelled this out in his Book of Pastoral Care:

The married must be admonished to bear in mind that they are united in wedlock for the purpose of procreation, and when they abandon themselves to immoderate intercourse, they transfer the occasion of procreation to the service of pleasure . . though they do not then pass beyond the bounds of wedlock, yet in wedlock they exceed its rights. Wherefore it is necessary that they should efface by frequent prayer what they befoul in the fair form of intercourse by the admixture of pleasure. ${ }^{33}$

Writing to the Canterbury mission, Gregory stated that parents should postpone the resumption of sexual relations after childbirth until the child was weaned, and he took the opportunity to comment on the "bad custom" of wet-nursing. ${ }^{34}$ His objections apparently were based on the mother's motives rather than the child's welfare; he castigated women whose "incontinence" prompted them to hand over their babies to nurses. The issue was sexual pleasure, and the pope's tone was harsh and critical, unlike the gentle tone of his sympathy with menstruating and pregnant women.

Like other moralists and preachers, Gregory moved back and forth between a reasonable, pastoral approach to women, whose special sorrows and difficulties he appreciated, and his fear of

médiéval, ed. Georges Duby and Jacques Le Goff (Rome: Ecole Française de Rome, I977).

3I. Bede, History I.27, pp. 77-78.

32. Ibid., p. 77.

33. Gregory the Great, St. Gregory the Great: Pastoral Care, trans. Henry Davis, S.J. (Westminster, Md.: Newman Press, 1950), 3.27, pp. I 88-I 89.

34. Bede, History I.27, p. 78 . 
"Woman," who was fatally associated with pleasure. "The Serpent suggested the first sin, and Eve, as flesh, took physical pleasure in it, while Adam, as spirit, consented. ${ }^{135}$ When Eve was not suffering, bringing forth children in sorrow, she was identified with pleasure and with sin. Gregory had no intention of falling into Adam's fatal mistake of consenting to her sin; it was one task of the Church to limit and control tragic reenactments of the primal drama. Suffering women-usually mothers or potential mothers, who suffered in their reproductive capacity-were welcome in church and entitled to pastoral care. Women who were not suffering, women experiencing and tempting men with physical pleasure, represented a continual threat to the well-being of all people, but particularly of celibate men. Gregory's writings, especially his Book of Pastoral Care, which was given to every bishop at his consecration, were extremely influential in the development of moral theology in the West. His profound ambivalence about women and Woman, pain and pleasure, has had a long life in the history of Christianity and of motherhood.

The subordination and protection of women were characteristic of the social relations and legal arrangements of Germanic societies long before the arrival of the missionaries. A woman lived within the mundium (protection and control) of her father or husband or another kinsman, whose status determined her social and legal position. Germanic societies controlled violence by making perpetrators pay compensation to the victims or their kin; the amount of this wergild varied with the status of the victim and the nature of the crime. Heavy sanctions were placed on rape, abortion, and the murder of women, with compensation paid to the men in whose mundium they belonged. Such efforts to protect women against violence and to discourage offenders may have been related to a significant imbalance in the sex ratio. Men outnumbered and outlived women throughout late antiquity and the early Middle Ages. In the eleventh or twelfth century, the balance was restored and began to move in the other direction; after the twelfth century, women outnumbered men.

Scholars agree that demographic reality shapes social relations

35. Ibid., p. 83 . 
but do not agree about the implications of the early medieval sex ratio. David Herlihy argued that the scarcity of women made them valuable, especially as potential mothers. He pointed to the laws of the Salian Franks, in which the wergild of a free female child was the same as that of a free man but tripled when the girl reached puberty and increased still more when she was pregnant; at menopause, her "value" reverted to that of a young girl or a man. In some cases the protection of females extended still further: among the Alemanni, the person responsible for causing an abortion was fined twice as heavily if the fetus was female. ${ }^{36}$

Persistent attention to the safety of women and girls may also imply that they were not so much valuable as vulnerable, objects of continual violence. Literary sources depict a society of warriors whose ethical system honored physical courage, loyalty from men to their leader, generosity from the leader to his men. In the world of Beowulf the only active female figure was Grendel's horrible mother. The important relationships were those of the heroes who fought side by side in battle and slept side by side in the lord's hall. Women, even the queen, were peripheral, and women of the lower classes had no existence, at least in the literary remains of the culture. Certain clauses of the legal codes reflect similar values: the Burgundian code, under the heading "Of Women Violated," required a "native freeman" who assaulted a maidservant to "pay twelve solidi to him to whom the maidservant belongs." ${ }^{37}$ Nothing we know about the societies of Germanic Europe is incompatible with the need to protect women against violence.

Most of the data for early medieval demographic studies come from ninth-century materials arising in societies very unlike those that produced either Beowulf or the laws of the Burgundians or Salian Franks. The surviving Carolingian documents served practical purposes as surveys or census reports of peasant households in agricultural communities. Figures taken from such documents indicate a strikingly uneven sex ratio, which has provoked varying interpretations. Female children may have been underreported by

36. Herlihy, "Life Expectancies," pp. 8-9.

37. The Burgundian Code, trans. Katherine Fischer Drew (Philadelphia: University of Pennsylvania Press, 1972), p. 44. 
their parents or ignored by census takers, although that explanation does not support the notion that their value was enhanced by scarcity. Men may have migrated into these relatively wellorganized farming communities to find work, and women may have emigrated to work as domestic servants or to marry, but migration alone was probably not sufficient to account for the sex ratio.

On the basis of the ninth-century census of households dependent on the abbey of St. Germain-des-Pres, Emily Coleman argues that girls may have been at special risk of infanticide. She found that the more numerous the family and the smaller the holding, the greater the preponderance of males. When the family was smaller and the holding larger, the sex ratio tended toward equality. Coleman believes that "too many" daughters could be disastrous in a marginal property: the holding was endangered if its resources were stretched to provide for each child, and young men with sisters at home could not marry and bring home wives. More comfortable families with fewer children could afford to keep all their daughters; the sex ratio evened out with prosperity. ${ }^{38}$ Given the high infant mortality of medieval Europe, a child who was not actively helped to live might easily die without provoking comment or intervention. Infanticide did not require much activity on the part of the parents. Of course it was forbidden by the Church, along with contraception and abortion, but such prohibitions are rarely effective; their existence testifies to a problem, not a solution.

It is generally assumed that the preponderance of males in early medieval Europe was somehow related to the death of women in childbirth or through complications of pregnancy. The reversal of the sex ratio later in the Middle Ages, however, occurred without significant advances in obstetrics or gynecology; maternal mortality is not in itself an adequate explanation for the demographic shift. It has been suggested that dietary deficiencies may help to account for the discrepancies. ${ }^{39}$ Until the eleventh century, when

38. Emily Coleman, "L'infanticide dans le Haut Moyen Age," Annales E.S.C. 29 (1974), 3 I 5-335.

39. This discussion is based on Vern Bullough and Cameron Campbell, "Female Longevity and Diet in the Middle Ages," Speculum 55 (1980), 317-325. See also 
more meat became available and iron cooking pots came into general use, most people consumed very little iron. The iron requirements of menstruating, pregnant, and lactating women are much higher than the requirements of men, too high to have been adequately supplied by the iron available in the diet of the earlier period. It is likely that women's lives were shortened by anemia, which usually does not cause death directly but significantly complicates blood loss-as in miscarriage, abortion, or childbirthand contributes to the mortality rate from respiratory disease. Iron deficiency cannot account for a preponderance of male infants, which appears in some documents and not in others, ${ }^{40}$ but it does answer some questions raised by the sex ratio in age groups past puberty. It helps to explain the stability of the European population before the eleventh century, when the increase in population overall may have been stimulated by an increase in dietary iron. Women who are seriously anemic do not menstruate or become pregnant, and thus anemia serves as a physiological mechanism for the adjustment of population to food supply. That interpretation of the demographic data does not exclude social interpretations, such as female infanticide or the underreporting of women and girls, but it does shed some light on a puzzling aspect of the history of motherhood in the medieval West.

Christian bishops and missionaries in the underdeveloped world of the early Middle Ages confronted the multiple challenges of converting, teaching, and supervising the faith and morals of illiterate people widely dispersed in rural areas-indeed, in wilderness-and powerfully attached to ancient social and religious cus-

the essential work of Lynn White on the agricultural revolution of the Middle Ages and its implications in Medieval Technology and Social Change (Oxford: Oxford University Press, 1982), pp. 69-76.

40. Using the polyptych of the abbey of St.-Germain-des-Pres /gathered between 801 and 829 ), Coleman, "L'infanticide," found the preponderance of males stable throughout the age groups; it varied with the size of the holding and the household, not with age. Using the surveys of the church of St. Victor of Marseilles and the monastery of Farfa, David Herlihy, "Life Expectancies," found that the preponderance of females among infants disappeared as the population aged: among adults, males predominated. 
toms. There were never enough priests, nor were most parish priests significantly better educated than the people they served. In this environment, the clergy made use of penitentials-teaching and disciplinary codes first developed by Irish monks- to assist them in parish work among lay people. Penitentials were produced in Ireland and England from the sixth century on, and later on the Continent. Sins were catalogued by subject and penances prescribed for each offense. The penitentials resembled Germanic legal codes in that penances varied according to the status of the offender: most sins were taken more seriously when committed by clerics than by lay people, by adults than by children, and so forth. As guides for the behavior of men and women in the world, the penitentials were not very appropriate: the penances themselves, which included prolonged bread-and-water fasts, were more suited to monks than to undernourished peasants. As historical sources they contribute less to our knowledge of lay people than to our understanding of the attitudes and morality of early monasticism.

The penitentials reflect a physical and intellectual environment far removed from that of the late Roman Empire. Pollution was a constant concern, and the eating and drinking of unclean things. ${ }^{41}$ The physical and moral health of the community were not sharply differentiated, and the clergy took responsibility for both. Strict rules protected sacred persons and objects against the perpetual danger of contamination. The "Bigotian Penitential" of the early eighth century warned clerics:

The penance of one who drinks what has been contaminated by a layman or a laywoman, one day on bread and water.

The penance of one who drinks what has been contaminated by a pregnant serving-woman, or for cohabitation with her, forty days on bread and water. ${ }^{42}$

4I. E.g., the "Canons of Adamnan" ruled that "a cistern in which is found either the corpse of a man or [the carcass] of a dog or of any animal is first to be emptied, and the slime in it, which the water has moistened, is to be thrown out, and it is clean"; see The Irish Penitentials, ed. Ludwig Bieler, (Dublin: Dublin Institute for Advanced Studies, I983), p. I 77.

42. Irish Penitentials, p. 217. 
The pregnant woman, apparently, was believed to be forty times less clean than the ordinary layperson; it is not clear whether her pregnancy or her social status was more dangerous.

Authors of penitentials frequently cited the Church Fathers. They taught the same faith and followed the same moral code, but their world, their concerns, and their reasons for writing were entirely different. They did not produce sermons or theology, and their works lacked the nuances of the writings of Jerome and Augustine. The authors were preparing handbooks-practical tools for confessors and religious leaders-and theological subtlety was neither necessary nor desirable. But these documents were strikingly unlike their patristic models, less in style than in cultural background. In speaking of marriage and motherhood they did not contradict the Church Fathers but placed their emphases differently. The later writers tended to focus on sexual and other kinds of pollution and on "magic" - that is, the use of herbs or spells for reproductive purposes, whether to promote fertility or impede conception or produce abortion. Various medical-religious practices were forbidden: the seventh-century "Penitential of Theodore" warns that "if any woman puts her daughter upon a roof or into an oven for the cure of a fever, she shall do penance for seven years." ${ }^{43}$

The conversion of the Germanic peoples to Christianity was not accomplished at once, and the clergy knew very well that many persons, especially in country places, followed the practices of their ancestors. (Indeed, this was still the case in the seventeenth century and later.) Medicine and religion were closely identified, and the Church tried hard to discourage attempts to control nature through supernatural means-unless, of course, such means were sanctioned by the Church, as were the relics and shrines of the saints. The writings of Christian historians and hagiographers are filled with tales of children who were taken, usually by their mothers, to saints' shrines, where they were cured of disorders ranging from birth defects to high fevers. Gregory of

43. Medieval Handbooks of Penance, ed. John T. McNeill and Helena M. Gamer (New York: Columbia University Press, 1938), p. I98. We do not know why daughters but not sons were treated by this method. 
Tours tells of one young girl, mute from birth, whose mother took her to the tomb of St. Martin, where her first word- "Good"was spoken in response to a question about the smell of incense at the shrine. Hearing that first sound, the mother tried another test: she placed holy water in her daughter's mouth and asked about the taste, and the girl again answered "Good." The joyful mother then took her child home, leaving her grief and anxiety at the saint's tomb. ${ }^{44}$ Such miraculous healings were perceived as direct interventions by the holy dead, whereas a woman who put her daughter on the roof was doing the devil's work.

Caesarius of Arles, a sixth-century bishop who with Gregory the Great formed an essential link in the transmission of patristic theology in the West, was a strict constructionist in sexual ethics. His attitude toward married lay people was unyielding: he equated contraception with homicide and threatened women with damnation if they did anything to impede conception. Chastity was the only acceptable way to avoid pregnancy. ${ }^{45}$ Leaders of the Church were concerned about concubinage and about the persistence of "superstitious" practices, not about the gynecological and social consequences of sexual activities inside or outside of marriage. Authors and compilers of penitentials, in contrast to such bishops as Caesarius, showed a certain appreciation of the complexity of human circumstances and made some distinctions:

A woman who causes miscarriage of that which she has conceived after it has been established in the womb, three years and a half of penance. If the flesh has formed, it is seven years. If the soul has entered it, fourteen years' penance. If the woman dies of the miscarriage, that is the death of body and soul, fourteen cumals [are offered] to God as the price of her soul, or fourteen years' penance. ${ }^{46}$

44. Gregory of Tours, "De virtutibus S. Martini" II.38, in Gregorii Turonensis opera, vol. I, pt. 2, ed. Bruno Krusch (Hanover: Hahn, I885), SRM, I:I72. I am indebted to Rosemary Hale for her interpretation of this story.

45. Caesarius said, "Chastity is the sole sterility of the Christian woman" (quoted in Noonan, Contraception, p. I46).

46. Medieval Handbooks, p. I66. A "cumal" was a female slave, defined as "a measure of value. . equivalent to three cows or twelve fatted fowls" (p. I I 9 n. I9). Regard for human life, especially female life, is always relative to class and status. 


\section{The Oldest Vocation}

Aristotle thought the fetus was "formed" and became human after a period of forty days for males and ninety for females. Most Christian thinkers adopted his views, although some believed that "ensoulment" occurred at conception. The author of this "Old Irish Penitential" apparently believed that the soul entered the fetus after its flesh was "formed." ${ }^{47}$

Although writers and compilers of penitentials did tend to copy older works, it is still safe to assume that repeated condemnations of certain practices indicate that such practices continued to exist and to cause problems. Variations and intriguing anomalies occasionally appear among the repetitions. In the "Penitential of Theodore," for example, a distinction is made in cases of infanticide:

If a mother slays her child, if she commits homicide, she shall do penance for fifteen years....

If a poor woman slays her child, she shall do penance for seven years. ${ }^{48}$

The distinction is based on class and resources, with no explicit statement about the relative morality of the two mothers. In an eighth-century version of this clause, pejorative language alters the meaning of the text and introduces a further distinction:

A mother who kills her child before the fortieth day shall do penance for one year. If it is after the child has become alive, [she shall do penance] as a murderess. But it makes a great difference whether a poor woman does it on account of the difficulty of supporting [the child] or a harlot for the sake of concealing her wickedness. ${ }^{49}$

A "harlot," of course, is assumed not to be poor!

In at least one document the consistent emphasis on the preservation of fetal life was turned around. From the sixth-century "Penitential of Finnian":

47. For a discussion of "formation" and "ensoulment," see Noonan, Contraception, pp. 89-9I.

48. Medieval Handbooks, p. I 97.

49. Ibid., p. 225. 


\section{SPIRITUAL MOTHERHOOD}

If a woman by her magic destroys the child she has conceived of somebody, she shall do penance for half a year with an allowance of bread and water, and abstain for two years from wine and meat and fast for the six forty-day periods with bread and water.

But if, as we have said, she bears a child and her sin is manifest, [she shall do penance] for six years [with bread and water], as is the judgement in the case of a cleric, and in the seventh year she shall be joined to the altar, and then we say her crown can be restored and she may don a white robe and be pronounced a virgin. ${ }^{50}$

The text suggests that abortion was taken less seriously than "illegitimate" pregnancy and birth, which involved public shame. The clause probably was designed for nuns, and the possibility of full restoration to "virginity" may account for the harsh penalty for bearing a child.

Interference with reproduction was taken very seriously, but so was marital intercourse; rules governing the behavior of husbands and wives were colored by the horror of contamination that pervades these documents. Gregory the Great had "accepted" menstruation as an unavoidable burden carried by women since the Fall, but authors of penitentials were inclined to equate it with pollution:

He who is in [the state of] matrimony ought to be continent ... after conception, and during the menstrual period to its very end.

After a birth he shall abstain, if it is a son for thirty-three [days]; if a daughter, for sixty-six [days]. ${ }^{51}$

Despite Gregory's insistence that menstruating women were welcome in church, the "Bigotian Penitential" states that "during their monthly period women should not enter a church nor receive holy communion." 52

The penitentials offer a rich, if somewhat bizarre, picture of the fears, interests, and passions of early medieval monks who were attempting to serve lay people as well as members of their own communities, and they naturally reveal more about the monks

50. Irish Penitentials, pp. 79, 8 I. I have not found similar suggestions in other penitentials.

5 I. Ibid., p. I 17.

52. Ibid., p. 223. 
than about the men, women, and children who were their penitents. Most of the texts address matters such as aggression, gluttony, and pride; many of them were associated with problems that arose in communities of men, with fears about eating and drinking and the danger of pollution of the Host. Mothers and children were present in the writers' consciousness but-with certain important exceptions-more as threats to monastic purity than as subjects of pastoral responsibility.

Early medieval historians, from Gregory of Tours and Bede to Paul the Deacon, historian of the Lombards, incorporated a great variety of stories into their works - tales of kings and queens, saints and villains. Occasionally, as in the case of Gregory's wicked queens and some of Bede's saints, the stories involve mothers and children. They rarely tell us much about the experience of motherhood, and they never are told from the mother's point of view, but they do represent certain attitudes of the historian and his society.

Gregory of Tours wrote about powerful, ambitious queens as well as holy female saints. Royal and aristocratic Merovingian society observed no significant distinctions between private and public; family dynamics and Frankish politics were one. The royal power rested on the king's strength and physical courage, his treasury, his family possessions, and his ability to attract and reward warrior companions. Power within a royal or noble family provided access to power outside. Royal women could more easily acquire and wield such power through motherhood than through marriage; the king's mother was much more secure than his consort. The Church had not yet imposed monogamy on its royal sons, and a wife or concubine could easily be supplanted by a rival. A king might have several wives, but only one mother. Furthermore, women inherited property and ruled their lands; often they were the guardians of fatherless children and of the children's property. Suzanne Wemple has commented: "loyalty to the uterine line was inculcated in aristocratic males in their early childhood, and hence we should not be surprised that Clotild asked her sons, not her husband, to avenge the murder of her parents. ${ }^{153}$

53. Suzanne F. Wemple, Women in Frankish Society: Marriage and the Cloister, soo to 900 (Philadelphia: University of Pennsylvania Press, 1985), p. 60. 
Without monogamy or primogeniture, loyalty was directed primarily toward mothers, children, and siblings; marriage was not the principal or exclusive bond that it later became. The tie between mother and child was likely to be the central relationship for both. When St. Monegund's daughters died, she left her husband and retired to a cell; she could bear her grief only by changing her life entirely. ${ }^{54}$ With her children gone, nothing kept her in the world-certainly not the needs or companionship of her husband. Monegund's story was not unique or even very unusual.

Children in stories about miraculous cures frequently appear to belong exclusively or especially to their mothers. (Of course, such children generally had something serious wrong with them.) St. Martin cured a child with terrible birth defects; both the mother and the author, Gregory of Tours, blamed the mother for the child's difficulties, for he had been conceived on a Sunday. ${ }^{55}$ Parents of both sexes were sternly warned of the possible consequences of such a sin, but it was clear that this child was his mother's responsibility. A powerful relationship existed between the moral and religious nature or status of parent and child and the physical processes of conception and birth. Gregory's own mother suffered from severe pains in her leg from the time of his birth until thirty-four years later, when Gregory was ordained and she came to visit St. Martin's shrine. ${ }^{56}$ Gregory did not explain the connection, but evidently he believed that his own changed status, as well as the saint's disposition to help sufferers, contributed to his mother's recovery, just as his birth was associated with the onset of her pain.

Women were responsible for the children born to them, and a woman who abandoned or killed her child was assumed to be promiscuous as well as desperate. Infanticide was associated with sexual depravity; the histories do not acknowledge the distinctions of wealth and poverty noted in some of the penitentials. With little sympathy to spare for women who gave birth outside of supportive social structures, historians usually characterized them as monstrous or "unnatural." In the eighth century Paul the Deacon told a story in which the mythic archetype of the fostering

54. Gregory of Tours, "Liber vitae patrum" XIX, I, in Opera, SRM, I:286.

55. Gregory of Tours, "De virtutibus" II.24, p. 167

56. Ibid., III. ro, p. 85. 


\section{The OLdest VOCATION}

of the hero illustrates the "protection" of women and children in early medieval Europe:

At this time a certain prostitute had brought forth seven little boys at a birth, and the mother, more cruel than all wild beasts, threw them into a fish-pond to be drowned. . . It happened therefore that when King Agelmund had stopped his horse and looked at the wretched infants, and had turned them hither and thither with the spear he carried in his hand, one of them put his hand on the royal spear and clutched it. The king moved by pity ... ordered him to be lifted from the fish-pond and commanded him to be brought to a nurse to be nourished with every care. ${ }^{57}$

The king was not kind enough to rescue the other six babies, but Paul does not call him cruel for "turning them over" with his spear. The mother was cruel and unnatural; the king was exceptionally compassionate and well rewarded by the heroic destiny of his foster child.

In recent years the lives of saints have been enthusiastically exploited as sources for many kinds of historical research. Their exemplary protagonists embody the ideals of a society, or at least of the hagiographer's particular segment of a society; and the background and context illuminate aspects of medieval life, including family and class relationships, that may not have been important to the hagiographer but are of great interest to historians.

The stated purpose of Rudolf, the monk who wrote "the Life of St. Leoba" in the ninth century, was to celebrate the holiness, learning, and power of Leoba, abbess of Bischofscheim and close friend of St. Boniface. As a foil to Leoba's virtues, the author told a story about another woman, "a certain poor little crippled girl." (In medieval stories, physical deformity or ugliness frequently exhibits moral evil-but not always: great saints such as St. Ber-

57. Paul the Deacon, History of the Lombards, ed. and trans. William Dudley Foulke (Philadelphia: University of Pennsylvania Press, I 974), I.4, p. 26. On the exposure of infants, see John E. Boswell, The Kindness of Strangers: The Abandonment of Children in Western Europe from Late Antiquity to the Renaissance (New York: Pantheon Books, I988). 
nard were praised for triumphing over physical weakness and illness.) The poor woman lived near the convent and was given food and clothing by the nuns. When she conceived a child, she concealed her pregnancy, and when the baby was born, she "cast it at night into a pool by the river which flowed through that place." A woman who came to draw water discovered the body and assumed that the child had been born to one of the nuns. She was utterly enraged, first at the hypocrisy of those who preached morality but did not practice it and then at the pollution of the pool. She spoke with furious irony:

How admirable is the life of nuns, who beneath their veils give birth to children and exercise at one and the same time the function of mothers and priests, baptising those to whom they have given birth. For, fellow-citizens, you have drawn off this water to make a pool, not merely for the purpose of grinding corn, but unwittingly for a new and unheard-of kind of Baptism. Now go and ask those women, whom you compliment by calling them virgins, to remove this corpse from the river and make it fit for us to use again. ${ }^{58}$

The story reveals powerful resentment on the part of the community served by these missionary nuns. Apparently they were believed to think themselves better than other people, and they may also have been seen as outsiders. (Leoba was an Englishwoman called by Boniface to help in the conversion of the Germans.) The concern about pollution, so prevalent in the penitentials, is prominent here too. When the mother threw her baby in the pool, "she added crime to crime, for she not only followed fleshly sin by murder, but also combined murder with the poisoning of the water." 59

In the end, Leoba forced a confession from that "wretched little woman, the dupe and the tool of the devil." ${ }^{60}$ The spiritual power of the abbess conquered the Father of Lies, who had arranged the

58. Rudolf, "The Life of Saint Leoba by Rudolf, Monk of Fulda," in AngloSaxon Missionaries in Germany, trans. C. H. Talbot (London: Sheed \& Ward, I 954), pp. 2 I 6-2 I 7. The topos of the nun who hides her pregnancy under her habit became a staple of U.S. anti-Catholic propaganda in the nineteenth century.

59. Ibid., p. 216.

6o. Ibid., p. 218. 
ugly situation in order to discredit the convent. For Leoba, the entire series of events was a matter of public standing and reputation. She performed a public miracle: flames surrounded the victim and drove her to confess. The point was to restore the good name of the nuns-indeed, to enhance their standing through evidence of divine favor. Neither the author nor, as far as we know, the nuns were interested in the private tragedy that produced the public spectacle.

In almost all early medieval lives of female saints, monastic authors presented "real" or significant motherhood as a spiritual rather than a biological relationship. Leoba had two mothers: the first was Aebbe, who gave birth long after "the onset of old age had deprived [her] of all hope of offspring." Aebbe conceived after a miraculous dream interpreted by her old nurse-another maternal figure - to mean that a daughter would be born and must be consecrated to God. The biblical topoi of elderly parents and miraculous dreams, common in saints' lives, marked Leoba as extraordinary. Such a child required supernatural as well as natural parenting, and when she was old enough, "her mother consecrated her and handed her over to Mother Tetta to be taught the sacred sciences." ${ }^{61}$

Tetta was abbess of Wimbourne, a strict and holy teacher, an appropriate mother for a saint. Like her mentor, the virgin Leoba became a perfect mother: as an abbess she was responsible for the nuns entrusted to her care and leadership. The miracle that cleared their name was a spiritual labor that called forth "tears and groans." When her "children" were ill she cared for them; one had been given up for dead when Leoba "blessed milk and poured it drop by drop down the throat of the sick nun."62 The patient recovered and outlived Leoba, as was fitting for a daughter.

The historian Bede, a great admirer of holy women, set forth some of the connections betwen virginity and spiritual motherhood. One of his favorites was Etheldreda, an East Anglian princess who was married to the king of the Northumbrians, with whom she lived for twelve years in "the glory of perpetual virginity."

6 I. Ibid., pp. 2 I O, 2 I I.

62. Ibid., pp. 2 I 8,22 I. 
When finally Etheldreda persuaded the king to allow her to retire to a convent, she became "the virgin mother of many virgins vowed to God. ${ }^{\prime 63}$ Bede's ode to Etheldreda illustrates the relationship between virginity and "true" motherhood, realized and represented by the Virgin Mary:

Fair maid, who gav'st the whole world's

Parent birth,

God gave thee grace. And by that grace empowered

How many virgin blossoms since have flowered! ${ }^{64}$

A woman could emulate Mary by remaining a virgin and acquiring spiritual offspring.

Bede wrote most admiringly of Hilda, abbess of the double monastery at Whitby, where kings went for counsel and future bishops learned their Scripture and theology. Hilda's father was sent into exile during her mother's pregnancy and died before she was born, a situation reflected in another wonderful dream presaging the birth of a saint. Hilda's mother dreamed that "he was suddenly taken away, and although she searched everywhere, she could find no trace of him. When all her efforts had failed, she discovered a most valuable jewel under her garments; and as she looked closely, it emitted such a brilliant light that all Britain was lit by its splendour." The jewel, of course, was Hilda, "whom all her acquaintances called Mother because of her wonderful devotion and grace." ${ }^{65}$

The term "Mother" carried overtones of profound respect, almost awe, in the writings of men whose stories celebrated holy virgins who presided over communities of women, and even of men (double monasteries, ruled by an abbess, were not uncommon in Anglo-Saxon England). For some privileged women, spiritual motherhood was an attractive alternative to the relentless biological cycle that brought weakness, illness, and early death to so many others. Poor women had no such opportunities, however, except in extraordinary circumstances; Bede's female saints came

63. Bede, History 4.19, pp.238-239.

64. Ibid., 4.20, p. 242.

65. Ibid., 4.23, p. 248 . 
from royal or noble families. These sources do not reveal exactly how vocational choices were made, but we observe that it was not unusual for the mother of a saint to predict or perceive in a dream her daughter's future. The saints were preternaturally holy as children: Leoba "had no interests other than the monastery and the pursuit of sacred knowledge." ${ }^{\prime 66}$ Infant sanctity certainly was read back into the lives of these women by hagiographers, but it is likely also that parents, nurses, and teachers did what educators do in every age: that is, plant and nourish and discover in children the traits they hope and expect to find. "Exceptional" children are quick to reward the expectations of significant adults, and the medieval mothers who dreamed of their daughters' excellence and singularity had a substantial part in making their dreams come true.

Histories, legal codes, penitentials, and saints' lives present fragmented images of women and children, formulaic in style and shaped by the wishes, fears, and fantasies of their (male, and usually clerical) authors. It is very difficult to find direct evidence about the experience of women in the early Middle Ages. We piece together scraps, and our speculation is highly colored by our own experience and imagination. Apart from a few letters, prayers, poems, and lives (usually of abbesses by nuns), women's writings are scarce, and writing by laywomen - that is, by biological mothers-even scarcer. For that reason, as well as its intrinsic interest, Dhuoda's Manual is enormously valuable.

Dhuoda belonged to a noble Frankish family. She married Bernard of Septimania, a cousin of the Carolingian kings, who was assigned to guard and govern the Spanish March by Louis the Pious in the 820 s. Bernard sent his wife and son William, born in 826 , to live apart from him-perhaps because, according to court gossip, he was the lover of the empress. He visited Dhuoda at least once, for a second son was born in $84 \mathrm{I}$, the year when Bernard fought on the losing side of the battle in which Charles the Bald defeated his rivals and became the new emperor. After the defeat, Bernard sent William to Charles's court as a hostage and took his

66. Rudolf, "Life of Leoba," p. 2 I I. 
infant son back to his own headquarters. Dhuoda-her older son dismissed to the dangerous life of a royal captive, her baby removed even before his baptism-was left alone. Clearly, the power and authority of the royal and noble mothers of Merovingian times were not available to her. Whether because her kin could not help her, or because of Bernard's status or character, or because of the changed times, Dhuoda was unable to protect herself or her children. It is significant that her writing betrays no sense that she was entitled to protection, and her advice to William does not urge loyalty to herself and her family. Dhuoda was no Merovingian queen; she regarded William as his father's child.

Dhuoda's Manual was written as William left to take up his paternal legacy of royal politics, war, and violence. His mother's fears were realistic: Bernard was put to death for treason in 843, and William followed him four years later. All Dhuoda could do, her only way of touching her son or taking part in his life after their separation, was to write. She chose a form that William could read and reread, a guide or handbook to keep beside him. The work was entirely for him: "From the beginning of this little book until the end, in style and in meaning . . . all of it, in every way, as you know, was written for the health of your soul and body. ${ }^{167}$ The Manual gave her a common project with her son, a way to remain a presence in his life.

Dhuoda built her book around a core of traditional suggestions for a Christian life lived in the world. Unlike most of our sources, the Manual is not monastic in spirit; William was raised to be a soldier, the father of a family, a vassal and a lord. His mother directed him to love and obey his father, to pray for his father's ancestors, to take his place in the line of warriors from which he was descended. Dhuoda's French translator, Pierre Riché, points out that her faith was a "religion of fatherhood," Dronke has described Dhuoda's universe as one "in which the bonds of loyalty to the human father, to the emperor, and to a Father God are seen concentrically. ${ }^{\prime 69}$ Mother and son alike were

67. Dhuoda: Manuel pour mons fils, ed. and trans. Pierre Riché (Paris: Cerf, I975l, p. 68.

68. Ibid., p. 27.

69. Dronke, Women Writers, p. 38. 
born into patriarchy; their choices were limited to the possibility of doing well or badly within that system. Dhuoda expected her son to come into his masculine power and hoped that he would use it well. She did not complain of Bernard's cruelty, and she allowed her sadness to break through only once or twice, observing "that most women in the world rejoice in living with their children, and that I, Dhuoda, am kept far away from you, my son William." ${ }^{70}$ She was a wife without a husband, a mother without children, but her losses did not weaken her passion and conviction.

The Manual belongs to the genre of the "Mirror for Princes," guides for young Christian noblemen, but the mirror reflects the features of the parent, not those of the child. The work gave Dhuoda a means of expression and a way to exert her maternal authority in the narrow sphere that remained. Even as she apologized for weakness, she claimed her strength: "In spite of my weakness, living unworthy among worthy women, I am still your mother. ${ }^{\prime 71}$ Begging God to endow William with grace and virtue, she prayed:

Let him be generous and prudent, loyal and brave,

let him never abandon moderation.

He will never have one like me to tell him this,

I who, though unworthy, am also his mother.

I who always, at all moments and all hours, am

asking you with all my strength: have mercy on him. ${ }^{72}$

Dhuoda's sense of her own authority was independent of her ability to control her own situation or protect her child. In the circumstances, her assurance was extraordinary. When she told William that although she had written the book, he must put it to use, she quoted St. Paul: "I have planted, Apollos watered; but God gave the increase" (I Cor. 3:6). She had done all she could: "I have fought a good fight, I have finished the course, I have kept the faith" (2 Tim. 4:7). At the end she spoke with the crucified

70. Dhuoda, Manuel, p. 72.

7 I. Ibid., p. 80.

72. Quoted in Dronke, Women Writers, p. 42. 
Christ: "It is finished." ${ }^{73}$ The power of love, and the conviction that her relationship with William was unique, made possible her identification with Paul and with Christ.

Dhuoda's Manual is one of the rare expressions of maternal consciousness that survives from medieval Europe and one of the most poignant of any age. Unlike the monastic authors, Dhuoda did not dismiss physical motherhood, but it was not the primary source of her love and confidence, which came from the intimacy of sixteen years. She was no Paula, abandoning her children to do God's work; nor Monica, whose special status derived from a remarkable son. Her understanding and experience of motherhood were not at all similar to those of her contemporary, St. Leoba, as perceived and described by Leoba's biographer. Dhuoda could not spare William or herself their patriarchal destiny, but she spoke for herself; she was not a creation of legend or fantasy or memory or imagination. Unlike most extant documents of the early Middle Ages, the Manual records the voice of an individual woman speaking to her child.

Dhuoda's Manual offers a glimpse of the world outside the limitations of monastic sources. By the ninth century, in the ideology of Christian monasticism, spiritual motherhood had replaced biological motherhood as a woman's most valuable work. The companionship of the early communities and the arena, where marital status and parenthood were of little consequence compared with faith and commitment, was long vanished. Through the intense ascetic zeal of the Church Fathers, it had been accepted in theory that marriage and motherhood disqualified women for heroism and spiritual grandeur, except for the mothers of exceptional children. Production and reproduction were separated, with "production" defined (in the spiritual and ecclesiastical realm) as active holiness, the work of prayer and charity, teaching and mission. Ordinary mothers could not be "productive" in this sense; their work was reproduction-a lesser sphere. Holy women were not deprived of the status of marriage and motherhood, however, for they were brides of Christ and mothers

73. Dhuoda, Manuel, p. 70. 
of holy persons and communities. Spiritual motherhood was the only religious leadership permitted to women; the term "mother," transformed, retained its ancient power.

Within the sphere of monastic ideology, the construction of spiritual motherhood was extremely significant, although its implications in the world outside are much less clear. Dhuoda's Manual reveals that at least among the noble classes, women had actually lost effective power in relation to their children during the centuries in which the Church was establishing its authority in western Europe. Dhuoda's plight was not mitigated by clerical reverence for spiritual motherhood, which was irrelevant to her and her children. Neither Church nor clergy came to her assistance-nor, as far as we know, did she expect that they would. Dhuoda, in fact, became one of the unfortunate women described by Jerome and by Gregory of Nyssa: a mother whose love for mortal children ended in sorrow and in loss. 